\title{
The Supply Adjustment Process in Retail Space Markets
}

John D. Benjamin* G. Donald Jud* * Daniel T Winkler $* * *$

\begin{abstract}
Previous research has reported that the real estate market for retail space is slow to adjust, however, comparatively little research has investigated the supply of retail space for individual metropolitan markets. This study presents our findings by metropolitan statistical area (MSA) of the mean retail space supply lag, the short- and long-run retail space supply elasticities with respect to retail sales and the response of retail space supply to interest rate changes. The considerable variation in mean retail space supply lags and supply elasticities for our sample of fifty-six major MSAs has important implications for investors, developers and others who hold financial stakes in the supply of retail space.
\end{abstract}

Benjamin, J. D., G. D. Jud, and D. T. Winkler. "The Supply Adjustment Process in Retail Space Markets." Journal of Real Estate Research, vol. 15, no. 3, 1998, pp. 297-303.

Made available courtesy of American Real Estate Society

\section{Introduction}

A number of articles focusing on real estate markets report that real estate investment is slow to adjust to changing market conditions (see Kling and McCue, 1987; Barth, Bradley, McKenzie and Sirmans, 1988; Wheaton and Torto, 1990; and Grenadier, 1995a,b). Among the sectors of the real estate market that have been found to be the slowest to adjust is the market for retail space (e.g., Benjamin, Jud and Okoruwa, 1993; Benjamin, Jud and Winkler, 1995; and Eppli and Shilling, 1995). This slow adjustment of supply, on average, is thought to produce more protracted real estate cycles (Kling and McCue, 1987; Wheaton and Torto, 1990; and Grenadier, 1995b). Although evidence of a slow adjustment process is important, research has yet to examine the nature of the adjustment process in more detail.

The particulars of the adjustment process have meaningful implications for investors, developers and others trying to interpret recent market conditions and to understand the direction of future supply changes. ${ }^{1}$ Several important questions about the adjustment process arise when examining retail space supply in particular metropolitan markets: (1) Is a long mean lag the result of some MSAs having a short lag with other MSAs possessing extremely long lags, or do the majority of MSAs have similarly long mean lags; (2) Is the elasticity of supply for retail space with respect to retail sales always inelastic in the short-run (long-run), and why might some MSAs

\footnotetext{
*Department of Finance and Real Estate, The American University, Washington, DC 20016 or jbenj@ american.edu.

**Department of Business Administration, University of North Carolina-Greensboro, Greensboro, NC 27412 or juddon@hamlet.uncg.edu.

***Department of Business Administration, University of North Carolina-Greensboro, Greensboro, NC 27412 or dtwinkle@hamlet.uncg.edu.
} 
have greater short-run (long-run) supply elasticities than others; (3) How do regulatory restrictions and land availability affect the elasticity of supply for retail space; and (4) Which MSAs have the greatest mean lags, and what implications and risks do large lags pose for developers? This paper addresses these consequential questions.

A unique feature of our analysis is its focus on the supply of retail space in individual metropolitan markets, an emphasis that has not heretofore received attention in more aggregative studies. ${ }^{2}$ The article provides evidence about the nature of the supply of new retail space in fifty-six major metropolitan statistical areas (MSAs) and how these markets respond to changes in retail sales and the cost of capital. The article is organized as follows. The second section develops a stock adjustment model of retail space investment. The third section describes the data and presents estimates of the model for major metropolitan markets. The final section summarizes relevant findings and their implications.

\section{A Stock-Adjustment Model of Retail Space Investment}

To examine the speed of adjustment for retail space investment by MSA, we employ a stock-adjustment model. The nature of retail real estate investment for new space or expansion of existing space is that construction dollars follow sales dollars. ${ }^{3} \mathrm{We}$ assume, therefore, that the desired stock of space $\left(K_{t}^{D}\right)$ is a function of real current sales $\left(S_{t}\right)$ along with the real interest rate $\left(r_{t}\right)$ which provides a proxy for changing new space development costs over the business cycle:

$$
K_{t}^{D}=\alpha^{\prime}+\beta_{1}^{\prime} S_{t}+\beta_{2}^{\prime} r_{t}+\varepsilon_{t}^{\prime},
$$

where $\varepsilon_{t}^{\prime}$ is the error term.

It is anticipated that the desired supply is positively related to sales and negatively related to capital costs.

Because retail space cannot be created instantly, but takes time to construct, developers can make only partial adjustments each period. ${ }^{4}$ Also, by making a partial adjustment, it is less likely that a developer will over build. The actual level of space $\left(K_{t}\right)$ in any period, therefore, is decided by an adjustment parameter $\delta$ that reflects how quickly developers want to move from the existing to the desired supply of space:

$$
K_{t}-K_{t-1}=\delta\left(K_{t}^{D}-K_{t-1}\right),
$$

where $K_{t}$ is the actual retail space, $K_{t-1}$ is the actual retail space lagged one period and $\delta$ is the adjustment speed.

Substituting Equation (1) into Equation (2) yields:

$$
K_{t}-K_{t-1}=\delta \alpha^{\prime}+\delta \beta S_{t}+\delta \beta r_{t}-\delta K_{t-1}+\delta \varepsilon,
$$

or, letting $\alpha=\delta \alpha^{\prime}, \beta_{1}=\delta \beta_{1}^{\prime}, \beta_{2}=\delta \beta_{2}^{\prime}, \beta_{3}=(1-\delta)$ and $\nu_{t}=\delta \varepsilon_{t}^{\prime}$ and rearranging: 


$$
K_{t}=\alpha+\beta_{1} S_{t}+\beta_{2} r_{t}+\beta_{3} K_{t-1}+\nu_{r}
$$

Equation (4) reveals that the current supply of retail property $\left(K_{t}\right)$ is a function of current sales $\left(S_{t}\right)$, the cost of capital $\left(r_{t}\right)$ and lagged retail space $\left(K_{t-1}\right)$. We expect that the current supply of retail property is a positive function of current sales and lagged space, and a negative function of the cost of capital. The error term $\left(\nu_{t}\right)$ in Equation (4) follows a moving average process (Pindyck and Rubinfeld, 1981, p. 236). ${ }^{5}$ Accordingly, we estimate our empirical models assuming that the error terms follow MA(1) and MA(2) processes; however, we also test for a first-order process that might occur separately or in concurrence with a moving average process. ${ }^{6}$

Estimates of the model in Equation (4) can reveal insights into the length of lags in supplying new or expanded retail space. For example, how long does it take a change in the desired supply of retail space to be actually built as new or expanded space? For investors, developers, lenders and other retail market professionals, the answer to this question has important implications. The adjustment time is revealed in the estimates of $\delta$, where the smaller the estimate of $\delta$, the longer the adjustment time before retail space is constructed. The mean lag of the adjustment process is $(1-\delta) / \delta$. So, for example, if $\delta$ is 0.25 , the mean lag would be 3 , indicating that in three years, one-half of the difference between the desired and the existing retail space supply will be constructed.

\section{Data and Estimation}

To estimate the investment model represented by Equation (4), we employ data for each of fifty-six MSAs with a 1991 population greater than 250,000. For most MSAs, the time period extends from years 1972-91. Retail sales data in 1987 dollars were obtained from Woods and Poole Economics, Inc. from data collected by the U.S. Department of Commerce. Estimates of the stock of retail space for each metropolitan area were provided by the F. W. Dodge Co. To proxy the cost of capital, the ten-year Treasury bond interest rates were extracted from the Citibank database and were adjusted for inflation.

An overview of the retail space supply regression results for the individual MSAs is shown in Exhibit 1. The average adjusted $\mathrm{R}^{2}$ is approximately $98 \%$, suggesting a good explanatory power for the regressions. Also, as the Durbin $h$ is approximately normally distributed with unit variance (Pindyck and Rubinfeld, 1981, p. 194), the low average $\mathrm{h}$-Statistic of 0.31 suggests that first-order serial correlation is not a problem in most cases. ${ }^{7}$ The mean sales coefficient of 0.07 indicates marginal sales per square foot to be approximately $\$ 141$, measured in 1987 dollars. $^{8}$

The short- and long-run elasticities of retail space with respect to retail sales provide response estimates of retail space supply to changes in retail sales. ${ }^{9}$ The short-run estimate of 0.12 indicates retail space is inelastic in the short-run, as a $1 \%$ change in retail sales results in only a $0.1 \%$ change in supply. ${ }^{10}$ In the long-run, however, the supply of space is almost unitarily elastic at a $0.9 \%$ change in space per $1 \%$ change in sales. ${ }^{11}$ 


\begin{tabular}{|c|c|c|}
\hline \multicolumn{3}{|c|}{$\begin{array}{c}\text { Exhibit } 1 \\
\text { Summary Statistics } \\
\text { Retail Space Supply for MSAs (1972-91) }\end{array}$} \\
\hline & Mean & Std. Dev. \\
\hline Retail Sales Coeff. & 0.07 & 0.06 \\
\hline Real Rate Coeff. & -37.12 & 73.73 \\
\hline Lagged Space Coeff. & 0.89 & 0.11 \\
\hline Adjusted $R^{2}$ & 0.98 & 0.04 \\
\hline Durbin $\mathrm{h}$ & 0.31 & 0.73 \\
\hline$e(s r)$ & 0.12 & 0.10 \\
\hline$e(/ r)$ & 0.94 & 2.01 \\
\hline
\end{tabular}

The real interest rate, as measured by the ten-year Treasury bond rate minus the inflation rate, appears to be negatively related to retail space. The individual MSA regressions, however, indicate statistical significance of the real interest rate coefficient for only fifteen of fifty-six regressions.

The lagged retail space coefficient of 0.890 indicates the mean lag is approximately 8.1 years. ${ }^{12}$ This long lag suggests very attenuated cycles in the retail space market. ${ }^{13}$ According to Grenadier (1995b) longer construction lags will increase the likelihood of over building and extend the presence of soft markets. Shorter construction lags would make a particular market or property type less vulnerable to periods of over supply.

The regression results for the individual MSAs are shown in Exhibit 2. The broad majority of the MSA regressions have Res in the range of $97 \%-99 \%$, and also have statistically significant regression coefficients. As expected, the retail sales and lagged space coefficients are positive in sign, while most of the real rate coefficients show a negative relation to retail space.

On balance, it appears that the retail sales coefficient is larger in lower cost markets such as cities in Florida; that is, developers might require retail sales per square foot to be less in such markets. Similarly, the lagged space coefficients appear closer to 1.0 for higher cost and more mature MSAs with less available space to build upon. For such MSAs, located mainly in the northeastern and midwestern states as well as in California, the mean lag is considerably longer than other markets.

For the MSA regressions showing statistically significant regression coefficients for retail sales and lagged space, and also possessing strong explanatory power, we calculate short- and long-run elasticity estimates and the mean lags. These estimates are shown in Exhibit 3. In particular, twenty-one of thirty-four MSAs show long-run elasticities greater than 1.0, and four have elasticities greater than 2.0. The supply of retail space is inelastic for all MSAs in the short-run; however, those MSAs with more 


\section{Exhibit 2}

Retail Space Regressions for 1972-91

\begin{tabular}{|c|c|c|c|c|c|c|c|}
\hline Name & Constant & $\begin{array}{l}\text { Retail } \\
\text { Sales }\end{array}$ & $\begin{array}{l}\text { Real } \\
\text { Estate }\end{array}$ & $\begin{array}{l}\text { Lagged } \\
\text { Space }\end{array}$ & Adj. $R^{2}$ & $h$ & $N$ \\
\hline \multirow[t]{2}{*}{ Anaheim/Santa Ana, CA } & 779.78 & 0.05 & -232.30 & 0.94 & 0.99 & 0.02 & 20 \\
\hline & 0.8 & 2.2 & -4.5 & 19.3 & & & \\
\hline \multirow[t]{2}{*}{ Atlanta, GA } & 5861.98 & 0.14 & -9.22 & 0.74 & 0.99 & 0.33 & 19 \\
\hline & 4.1 & 8.4 & -0.2 & 18.8 & & & \\
\hline \multirow[t]{2}{*}{ Austin, TX } & 50.76 & 0.15 & -85.94 & 0.79 & 0.99 & 0.49 & 18 \\
\hline & 0.1 & 3.2 & -1.3 & 12.4 & & & \\
\hline \multirow[t]{2}{*}{ Baltimore, MD } & 4870.14 & 0.07 & 60.70 & 0.83 & 0.98 & -0.49 & 19 \\
\hline & 1.2 & 1.5 & 0.6 & 6.7 & & & \\
\hline \multirow[t]{2}{*}{ Birmingham, AL } & -1635.50 & 0.09 & 21.74 & 0.92 & 0.97 & -0.14 & 19 \\
\hline & -0.6 & 1.5 & 0.4 & 6.7 & & & \\
\hline \multirow[t]{2}{*}{ Boston, MA } & 12644.84 & 0.01 & -93.52 & 0.89 & 0.80 & 0.97 & 19 \\
\hline & 0.7 & 2.6 & -2.7 & 6.5 & & & \\
\hline \multirow[t]{2}{*}{ Charlotte, NC } & -2788.94 & 0.09 & -97.94 & 0.97 & 0.99 & 1.71 & 20 \\
\hline & -2.5 & 2.6 & -2.3 & 14.7 & & & \\
\hline \multirow[t]{2}{*}{ Chicago, IL } & -17914.34 & 0.06 & -128.01 & 1.00 & 0.99 & 1.85 & 20 \\
\hline & -2.1 & 2.1 & -0.9 & 36.4 & & & \\
\hline \multirow[t]{2}{*}{ Cincinnati, OH-KY-IN } & -1538.33 & 0.08 & -65.34 & 0.95 & 0.99 & -0.96 & 19 \\
\hline & -0.3 & 2.2 & -1.4 & 9.5 & & & \\
\hline \multirow[t]{2}{*}{ Cleveland, $\mathrm{OH}$} & 17044.33 & 0.03 & -116.02 & 0.84 & 0.88 & 0.28 & 19 \\
\hline & 1.1 & 0.4 & -1.5 & 7.9 & & & \\
\hline \multirow[t]{2}{*}{ Columbus, $\mathrm{OH}$} & 9693.11 & 0.13 & -12.18 & 0.79 & 0.98 & -0.35 & 19 \\
\hline & 1.4 & 3.9 & -0.3 & 7.9 & & & \\
\hline \multirow[t]{2}{*}{ Dallas, TX } & 685.24 & 0.11 & 11.54 & 0.81 & 0.99 & 0.47 & 19 \\
\hline & 0.2 & 3.2 & 0.1 & 13.5 & & & \\
\hline \multirow[t]{2}{*}{ Denver, CO } & 1203.91 & 0.04 & 64.30 & 0.93 & 0.99 & -0.13 & 19 \\
\hline & 0.5 & 1.0 & 0.8 & 22.2 & & & \\
\hline \multirow[t]{2}{*}{ Detroit, MI } & -17315.07 & 0.07 & 50.12 & 1.00 & 0.99 & 1.37 & 20 \\
\hline & -3.4 & 3.4 & 0.4 & 34.6 & & & \\
\hline \multirow[t]{2}{*}{ Fort Lauderdale, FL } & -4395.45 & 0.19 & -121.75 & 0.78 & 0.99 & 0.13 & 16 \\
\hline & -3.4 & 3.9 & -4.7 & 11.2 & & & \\
\hline \multirow[t]{2}{*}{ Fort Worth, TX } & -1072.85 & 0.13 & -49.73 & 0.85 & 0.99 & 1.32 & 19 \\
\hline & -0.7 & 3.0 & -0.6 & 14.0 & & & \\
\hline \multirow[t]{2}{*}{ Greensboro, NC } & 1308.98 & 0.07 & 11.35 & 0.89 & 0.99 & 0.24 & 19 \\
\hline & 0.7 & 1.2 & 0.2 & 8.1 & & & \\
\hline \multirow[t]{2}{*}{ Greenville, SC } & -585.10 & 0.06 & -57.66 & 0.98 & 0.99 & -0.00 & 19 \\
\hline & -2.1 & 2.0 & -3.3 & 20.9 & & & \\
\hline \multirow[t]{2}{*}{ Hartford, CT } & 14223.75 & 0.03 & -46.25 & 0.64 & 0.83 & 0.24 & 19 \\
\hline & 2.8 & 2.2 & -1.5 & 5.3 & & & \\
\hline \multirow[t]{2}{*}{ Honolulu, HI } & -955.10 & -0.03 & -80.64 & 1.15 & 0.99 & -1.48 & 19 \\
\hline & -0.5 & -0.9 & -1.5 & 7.8 & & & \\
\hline \multirow[t]{2}{*}{ Houston, TX } & -158.65 & 0.06 & -76.08 & 0.93 & 0.99 & 0.62 & 19 \\
\hline & $<-0.1$ & 2.9 & -0.5 & 30.6 & & & \\
\hline Indianapolis, IN & 2395.44 & 0.06 & 13.03 & 0.87 & 0.99 & 0.45 & 19 \\
\hline & 2.2 & 2.6 & 0.3 & 19.6 & & & \\
\hline Jacksonville, FL & -2923.17 & 0.14 & -25.94 & 0.89 & 0.99 & -0.14 & 17 \\
\hline & -3.3 & 2.6 & -0.6 & 10.4 & & & \\
\hline Kansas City, MO-KS & -531.12 & 0.12 & 24.2 & 0.85 & 0.99 & 0.03 & 19 \\
\hline & -1.1 & 3.4 & 0.7 & 18.2 & & & \\
\hline
\end{tabular}


Exhibit 2 (continued)

Retail Space Regressions for 1972-91

\begin{tabular}{|c|c|c|c|c|c|c|c|}
\hline Name & Constant & $\begin{array}{l}\text { Retail } \\
\text { Sales }\end{array}$ & $\begin{array}{l}\text { Real } \\
\text { Estate }\end{array}$ & $\begin{array}{l}\text { Lagged } \\
\text { Space }\end{array}$ & Adj. $R^{2}$ & $h$ & $N$ \\
\hline Las Vegas, NV & $\begin{array}{c}-2633.04 \\
-7.3\end{array}$ & $\begin{array}{l}0.14 \\
4.0\end{array}$ & $\begin{array}{c}-133.50 \\
-9.8\end{array}$ & $\begin{array}{c}0.95 \\
18.7\end{array}$ & 0.99 & 0.67 & 19 \\
\hline Los Angeles, CA & $\begin{array}{c}5530.03 \\
0.7\end{array}$ & $\begin{array}{l}0.08 \\
2.8\end{array}$ & $\begin{array}{c}80.39 \\
0.5\end{array}$ & $\begin{array}{c}0.85 \\
11.8\end{array}$ & 0.99 & 0.23 & 19 \\
\hline Miami, FL & $\begin{array}{c}-760.50 \\
-0.5\end{array}$ & $\begin{array}{l}0.07 \\
2.0\end{array}$ & $\begin{array}{c}137.71 \\
6.4\end{array}$ & $\begin{array}{c}0.89 \\
17.9\end{array}$ & 0.99 & 0.84 & 16 \\
\hline Milwaukee, WI & $\begin{array}{c}5530.03 \\
0.7\end{array}$ & $\begin{array}{l}0.08 \\
2.8\end{array}$ & $\begin{array}{c}80.39 \\
0.5\end{array}$ & $\begin{array}{c}0.85 \\
11.8\end{array}$ & 0.99 & 0.23 & 19 \\
\hline Minneapolis, MN & $\begin{array}{c}-1076.97 \\
0.6\end{array}$ & $\begin{array}{l}0.04 \\
5.2\end{array}$ & $\begin{array}{c}-103.90 \\
-7.7\end{array}$ & $\begin{array}{l}0.95 \\
32.6\end{array}$ & 0.99 & 0.40 & 19 \\
\hline Nashville, TN & $\begin{array}{c}-2501.85 \\
-15.5\end{array}$ & $\begin{array}{l}0.01 \\
0.7\end{array}$ & $\begin{array}{c}-42.50 \\
-1.9\end{array}$ & $\begin{array}{c}1.08 \\
33.1\end{array}$ & 0.99 & 0.57 & 19 \\
\hline Nassau/Suffolk, NY & $\begin{array}{c}39466.11 \\
3.7\end{array}$ & $\begin{array}{c}<0.01 \\
0.8\end{array}$ & $\begin{array}{c}-126.01 \\
-4.2\end{array}$ & $\begin{array}{l}0.52 \\
4.2\end{array}$ & 0.90 & 0.24 & 19 \\
\hline New Orleans, LA & $\begin{array}{c}2109.90 \\
0.6\end{array}$ & $\begin{array}{l}-0.02 \\
-0.3\end{array}$ & $\begin{array}{c}35.79 \\
0.5\end{array}$ & $\begin{array}{l}1.00 \\
21.3\end{array}$ & 0.99 & 1.12 & 18 \\
\hline New York City, NY & $\begin{array}{c}-2991.47 \\
-0.8\end{array}$ & $\begin{array}{l}0.01 \\
1.0\end{array}$ & $\begin{array}{c}-47.65 \\
-1.2\end{array}$ & $\begin{array}{c}1.00 \\
76.8\end{array}$ & 0.99 & 1.35 & 20 \\
\hline Newark, NJ & $\begin{array}{c}8938.47 \\
1.4\end{array}$ & $\begin{array}{c}<0.01 \\
0.3\end{array}$ & $\begin{array}{c}-26.03 \\
-0.7\end{array}$ & $\begin{array}{l}0.83 \\
6.4\end{array}$ & 0.93 & -1.05 & 19 \\
\hline Norfolk, VA & $\begin{array}{c}235.21 \\
0.3\end{array}$ & $\begin{array}{l}0.12 \\
3.3\end{array}$ & $\begin{array}{c}-36.52 \\
-0.8\end{array}$ & $\begin{array}{c}0.80 \\
11.3\end{array}$ & 0.99 & 0.25 & 19 \\
\hline Oakland, CA & $\begin{array}{c}-1165.21 \\
-0.6\end{array}$ & $\begin{array}{l}0.03 \\
1.1\end{array}$ & $\begin{array}{c}-96.49 \\
-1.9\end{array}$ & $\begin{array}{c}0.98 \\
11.8\end{array}$ & 0.99 & -0.31 & 20 \\
\hline Oklahoma City, OK & $\begin{array}{c}805.40 \\
0.5\end{array}$ & $\begin{array}{l}0.03 \\
1.1\end{array}$ & $\begin{array}{c}-19.08 \\
-0.3\end{array}$ & $\begin{array}{l}0.96 \\
27.1\end{array}$ & 0.99 & 2.64 & 20 \\
\hline Orlando, FL & $\begin{array}{c}-1451.14 \\
-1.7\end{array}$ & $\begin{array}{l}0.23 \\
4.4\end{array}$ & $\begin{array}{c}27.77 \\
0.4\end{array}$ & $\begin{array}{l}0.64 \\
6.6\end{array}$ & 0.90 & 0.22 & 16 \\
\hline Philadelphia, PA-NJ & $\begin{array}{c}8809.29 \\
0.8\end{array}$ & $\begin{array}{l}0.02 \\
1.3\end{array}$ & $\begin{array}{c}-29.17 \\
-0.3\end{array}$ & $\begin{array}{c}0.91 \\
10.1\end{array}$ & 0.98 & 0.23 & 19 \\
\hline Phoenix, AZ & $\begin{array}{c}-922.18 \\
-1.0\end{array}$ & $\begin{array}{l}0.09 \\
3.5\end{array}$ & $\begin{array}{c}-216.70 \\
-3.2\end{array}$ & $\begin{array}{c}0.91 \\
23.0\end{array}$ & 0.99 & 0.71 & 19 \\
\hline Pittsburgh, PA & $\begin{array}{c}2291.72 \\
0.4\end{array}$ & $\begin{array}{l}-0.01 \\
-0.1\end{array}$ & $\begin{array}{l}-2.04 \\
-0.03\end{array}$ & $\begin{array}{c}0.99 \\
17.1\end{array}$ & 0.98 & 0.14 & 19 \\
\hline Portland, OR & $\begin{array}{c}-1469.15 \\
-2.0\end{array}$ & $\begin{array}{l}0.01 \\
0.2\end{array}$ & $\begin{array}{c}-124.37 \\
-3.6\end{array}$ & $\begin{array}{l}1.05 \\
19.2\end{array}$ & 0.99 & 0.60 & 20 \\
\hline Richmond, VA & $\begin{array}{c}-1252.19 \\
-1.8\end{array}$ & $\begin{array}{l}0.07 \\
1.8\end{array}$ & $\begin{array}{c}-32.73 \\
-1.2\end{array}$ & $\begin{array}{c}0.95 \\
10.9\end{array}$ & 0.99 & 1.72 & 20 \\
\hline Riverside, CA & $\begin{array}{c}-2740.32 \\
-3.1\end{array}$ & $\begin{array}{l}0.01 \\
0.3\end{array}$ & $\begin{array}{c}-37.10 \\
-0.6\end{array}$ & $\begin{array}{c}1.08 \\
10.5\end{array}$ & 0.99 & -0.18 & 19 \\
\hline Sacramento, CA & $\begin{array}{c}-823.18 \\
-1.6\end{array}$ & $\begin{array}{l}0.06 \\
2.01\end{array}$ & $\begin{array}{c}-74.12 \\
-2.3\end{array}$ & $\begin{array}{c}0.94 \\
14.9\end{array}$ & 0.99 & 0.61 & 19 \\
\hline St. Louis, MO-IL & $\begin{array}{c}-861.01 \\
-0.6\end{array}$ & $\begin{array}{l}0.05 \\
5.4\end{array}$ & $\begin{array}{c}-52.65 \\
-2.7\end{array}$ & $\begin{array}{c}0.93 \\
31.4\end{array}$ & 0.99 & 0.15 & 19 \\
\hline Salt Lake City, UT & $\begin{array}{c}4374.09 \\
1.1\end{array}$ & $\begin{array}{l}0.16 \\
2.0\end{array}$ & $\begin{array}{c}91.80 \\
1.0\end{array}$ & $\begin{array}{l}0.75 \\
5.5\end{array}$ & 0.99 & -0.31 & 19 \\
\hline San Antonio, TX & $\begin{array}{c}-941.79 \\
-0.8\end{array}$ & $\begin{array}{l}0.13 \\
3.4\end{array}$ & $\begin{array}{c}-41.81 \\
-0.8\end{array}$ & $\begin{array}{c}0.85 \\
16.8\end{array}$ & 0.99 & 0.04 & 19 \\
\hline San Diego, CA & $\begin{array}{c}1177.59 \\
0.9\end{array}$ & $\begin{array}{l}0.07 \\
1.6\end{array}$ & $\begin{array}{c}-30.32 \\
-0.3\end{array}$ & $\begin{array}{l}0.89 \\
9.3\end{array}$ & 0.99 & -0.73 & 19 \\
\hline
\end{tabular}


Exhibit 2 (continued)

Retail Space Regressions for 1972-91

\begin{tabular}{|c|c|c|c|c|c|c|c|}
\hline Name & Constant & $\begin{array}{l}\text { Retail } \\
\text { Sales }\end{array}$ & $\begin{array}{l}\text { Real } \\
\text { Estate }\end{array}$ & $\begin{array}{l}\text { Lagged } \\
\text { Space }\end{array}$ & Adj. $R^{2}$ & $h$ & $N$ \\
\hline \multirow[t]{2}{*}{ San Francisco, CA } & 1944.98 & $<0.01$ & 1.00 & 0.97 & 0.97 & 0.14 & 20 \\
\hline & 0.3 & 0.2 & $<0.1$ & 8.3 & & & \\
\hline \multirow[t]{2}{*}{ San Jose, CA } & 974.34 & 0.02 & -74.81 & 0.95 & 0.99 & 0.29 & 19 \\
\hline & 0.8 & 1.0 & -2.2 & 15.0 & & & \\
\hline \multirow[t]{2}{*}{ Seattle, WA } & 9324.32 & 0.10 & 90.74 & 0.72 & 0.99 & 0.10 & 19 \\
\hline & 2.3 & 3.1 & 1.4 & 6.8 & & & \\
\hline \multirow[t]{2}{*}{ Tampa, FL } & 653.18 & 0.10 & -6.28 & 0.84 & 0.99 & 0.26 & 16 \\
\hline & 1.5 & 3.0 & -0.2 & 13.0 & & & \\
\hline \multirow[t]{2}{*}{ Tulsa, OK } & 488.66 & 0.05 & -46.45 & 0.93 & 0.99 & 0.47 & 19 \\
\hline & 0.3 & 1.1 & -0.8 & 18.0 & & & \\
\hline \multirow[t]{2}{*}{ Washington, DC-MD-VA } & -3317.23 & 0.06 & -154.68 & 0.94 & 0.99 & -0.98 & 17 \\
\hline & -1.0 & 3.2 & -2.2 & 15.2 & & & \\
\hline \multirow[t]{2}{*}{ West Palm Beach, FL } & -2168.36 & 0.19 & -27.60 & 0.77 & 0.99 & -0.18 & 16 \\
\hline & -2.0 & 3.0 & -0.4 & 7.7 & & & \\
\hline
\end{tabular}

Note: $t$-values appear beneath the coefficients.

available land appear somewhat more elastic. The average long-run elasticity for the MSAs shown in Exhibit 3 is 1.4, with a range of 0.5 to 5.1.

Among possible explanations for the wide differences in the long-run elasticity of supply across MSAs are differences in the availability and cost of land. ${ }^{14}$ Measuring inter-metropolitan differences in the availability and cost of land is difficult, and we have been able to uncover only a handful of studies dealing with the issue. These studies are reviewed in Rose (1989a). In a related paper, Rose (1989b) develops a metropolitan land supply index that measures the extent to which topographical factors restrict the supply of urban land.

The following regression reports the relationship between the Rose land supply index (LND) where higher values represent greater land availability and our long-run metropolitan supply elasticities shown in Exhibit 3 ( $t$-values in parenthesis):

$$
E_{L R}=\underset{(0.4)}{0.112}+\underset{(2.9)}{1.149} * \text { LND } \quad n=24 \quad R^{2}=.17
$$

The equation is estimated with the White procedure for heteroskedasticity-consistent standard errors. The coefficient on the land supply variable is positive and significant at the .01 level, suggesting that in markets where land is more available, the supply of retail space is more elastic. 


\section{Exhibit 3}

Retail Space Supply Elasticities and Mean Lags

\begin{tabular}{|c|c|c|c|}
\hline MSA & $\begin{array}{l}\text { Short-Run } \\
\text { Elasticity }\end{array}$ & $\begin{array}{l}\text { Long-Run } \\
\text { Elasticity }\end{array}$ & $\begin{array}{l}\text { Mean Lag } \\
\text { (Years) }\end{array}$ \\
\hline Anaheim/Santa Ana, CA & 0.09 & 1.44 & 15.56 \\
\hline Atlanta, GA & 0.23 & 0.87 & 2.84 \\
\hline Austin, TX & 0.24 & 1.13 & 3.65 \\
\hline Boston, MA & 0.02 & 0.87 & 8.12 \\
\hline Charlotte/Gastonia, NC-SC & 0.13 & 1.26 & $>20.00$ \\
\hline Chicago, IL & 0.10 & 0.69 & $>20.00$ \\
\hline Cincinnati, $\mathrm{OH}-\mathrm{KY}-\mathrm{IN}$ & 0.08 & 1.52 & 17.48 \\
\hline Columbus, $\mathrm{OH}$ & 0.11 & 0.50 & 3.67 \\
\hline Dallas, TX & 0.21 & 1.11 & 4.18 \\
\hline Detroit, MI & 0.14 & 0.87 & $>20.00$ \\
\hline Fort Lauderdale, FL & 0.36 & 1.26 & 3.64 \\
\hline Fort Worth/Arlington, TX & 0.21 & 0.69 & 5.62 \\
\hline Greenville/Spartanburg, SC & 0.08 & 3.83 & $>20.00$ \\
\hline Houston, TX & 0.11 & 1.58 & 12.27 \\
\hline Indianapolis, IN & 0.10 & 0.78 & 6.44 \\
\hline Jacksonville, FL & 0.26 & 2.39 & 8.26 \\
\hline Kansas City, MO-KS & 0.17 & 1.16 & 5.69 \\
\hline Las Vegas, NV & 0.25 & 5.11 & 19.60 \\
\hline Los Angeles/Long Beach, CA & 0.14 & 1.58 & 5.74 \\
\hline Miami, FL & 0.14 & 0.87 & 8.42 \\
\hline Milwaukee, WI & 0.13 & 1.26 & 5.74 \\
\hline Minneapolis/St. Paul, MN-WI & 0.06 & 0.69 & 17.54 \\
\hline Norfolk/Virginia Beach, VA & 0.22 & 0.87 & 4.07 \\
\hline Orlando, FL & 0.44 & 1.22 & 1.80 \\
\hline Phoenix, AZ & 0.16 & 1.78 & 10.47 \\
\hline Richmond/Petersburg, VA & 0.13 & 2.49 & 17.89 \\
\hline Sacramento, CA & 0.11 & 1.87 & 15.46 \\
\hline St. Louis, MO-IL & 0.09 & 1.28 & 13.51 \\
\hline Salt Lake City/Ogden, UT & 0.17 & 1.58 & 2.96 \\
\hline San Antonio, TX & 0.21 & 0.87 & 5.46 \\
\hline Seattle/Everett, WA & 0.16 & 0.57 & 2.59 \\
\hline Tampa/St. Petersburg, FL & 0.19 & 1.17 & 5.06 \\
\hline Washington, DC-MD-VA & 0.12 & 1.58 & 14.43 \\
\hline West Palm Beach/Boca Raton, FL & 0.37 & 0.87 & 3.27 \\
\hline
\end{tabular}

\section{Implications and Conclusion}

The focus of this study is the supply of retail space in individual metropolitan markets. From this research, we gather considerable insight into the mean lag in the building of retail space, the responsiveness of construction of new space to changes in retail sales (supply elasticity) for both the short- and long-run, and the effect of land supply on the supply elasticity.

The stock adjustment model of retail space investment indicates a long mean lag of approximately 8.1 years, although it ranges by MSA from as little as approximately 2 years to over 20 years. Higher cost and more mature MSAs (notably those in 
midwestern states, northeastern states and California) with less developable land possess the longer mean lags. Longer mean lags may be advantageous for developers who are able to expedite the approval process and construction more quickly than competitors, as these developers would be able to enjoy higher rents emanating from a market of strong demand and deficient supply.

As expected, the supply elasticities with respect to changes in retail sales are inelastic in the short-run for all metropolitan markets. The highly inelastic nature of some MSAs such as Boston MA, Chicago IL and St. Louis MO could be attributable to the age of these cities and the shortage of available developable land. Also, in these cities and others, local and state regulatory restrictions could explain the inelastic supply.

In the long-run, however, supply elasticities are much more elastic. Only thirteen MSAs of the thirty-four MSAs whose elasticities we were able to calculate have retail space supply elasticities less than one, leaving approximately $62 \%$ categorized as having an elastic supply. The elastic supply MSAs by definition are those markets that are quite responsive to changes in retail sales. Therefore, elastic-supply MSAs are more inclined to be over built. Developers impacted hardest in the elastic-supply MSAs would be newcomers late in the expansion phase of the business cycle. ${ }^{15}$ When faced with a long mean lag in construction, such developers would be likely to encounter large vacancies and the prospect of reduced rents. Examples of metropolitan markets indicating an elastic supply include Las Vegas NV,_ Greenville SC and Richmond VA. These MSAs appear relatively free from topographical factors that restrict the supply of urban land, and in fact, one might expect elastic supply MSAs to be more often associated with metropolitan markets with an ample land supply. Using the metropolitan land supply index developed by Rose (1989b), we confirm a positive relation between the land supply index and long-run metropolitan supply elasticities.

In conclusion, while our findings lend some insight into the supply of retail space in metropolitan markets, more research is needed. Specifically, we did not examine the influence of state and local regulatory restrictions or concentration of ownership on the supply of retail space. These areas should provide a fertile expanse for future research as more regulatory and ownership concentration indexes become more prevalent and refined.

\section{Notes}

1Academic explanations of real estate cycles focus on oversupply caused by long construction lags and easy financing or undersupply caused by developer reluctance to create new supply even in the presence of rising demand. See Grenadier (1995b) for further discussion.

2In prior studies of retail space adjustment, Benjamin, Jud and Okoruwa (1993), Benjamin, Jud and Winkler (1995) and Eppli and Shilling (1995) focus on national or state retail markets.

3 It is important to note that the stock-adjustment model presented represents a retail space investment model rather than a supply function. As this study does not estimate a demand function, therefore, market equilibrium values are not observed. 
${ }^{4}$ Developers begin construction based on estimates of future demand and supply for retail space. Information asymmetry about other developers' plans also compounds decisions to construct or expand retail space. Some markets have better mechanisms than other markets for information dissemination about new construction activities such as F.W. Dodge's "Pipeline" construction reporting service.

${ }^{5}$ This can be seen by rewriting Equation (4) having lagged the model one period and then substituting for $K_{t-1}$. Following this procedure yields:

$$
\begin{aligned}
K_{t}= & \alpha+\beta_{1}\left[S_{t}+(1-\delta) S_{t-1}+(1-\delta)^{2} S_{t-2}+\ldots\right] \\
& +\beta_{2}\left[r_{t}+(1-\delta) r_{t-1}+(1-\delta)^{2} r_{t-2}+\ldots\right]+z_{t}
\end{aligned}
$$

and the error term is $z_{t}=\delta e_{t}+\delta(1-\delta) e_{t-1}+\delta(1-\delta)^{2} e_{t-1}+\ldots$

${ }^{6}$ Because the model contains a lagged dependent variable, the standard Durbin-Watson test for autocorrelation is not valid. As an alternative we employ the procedure suggested by Durbin (1970) (Greene, 1993, p. 454) that uses a Lagrange multiplier test that is unaffected by the lagged dependent variable. The test statistic is:

$$
h=(1-D W / 2)^{*}\left(T /\left(1-T^{*} s_{x}^{2}\right)\right)^{1 / 2}
$$

where $D W$ is the traditional Durbin-Watson statistic, $s_{x}^{2}$ is the estimated variance of the least squares regression coefficient on $K_{t-1}$ and $T$ is the number of observations in the regression. The $h$-Statistic is $\mathrm{N}(0,1)$ so that large values of $h$ lead to a rejection of $H_{0}$ : no serial correlation (see, Pindyck and Rubinfeld, 1981, pp. 194-5.

${ }^{7}$ The individual Durbin $h$ are shown in Exhibit 2. Corrections for serial correlation occurred when the $h$-Statistic exceeded the critical value of the normal distribution at the $5 \%$ level.

${ }^{8}$ Retail sales and retail space are expressed in $\$ 100,000$ and 1,000 s, respectively. Therefore, marginal sales per square foot is $\$ 141=(1 / 0.0708) * 10$.

${ }^{9}$ The short- and long-run elasticities for retail sales are calculated as follows:

$$
\begin{aligned}
& E_{S R}=\beta_{1}\left(\frac{\bar{S}_{t}}{\bar{K}_{t}}\right) \\
& E_{L R}=\frac{\beta_{1}}{1-\beta_{3}}\left(\frac{\bar{S}_{t}}{\bar{K}_{t}}\right)
\end{aligned}
$$

where bar denotes the mean value of retail sales $(S)$ and retail space $(K)$.

${ }^{10}$ The adjustment toward equilibrium retail space may be slow due to zoning changes, construction permits and financing approvals along with other delays normally associated with the development process.

${ }^{11}$ Developers understand that the state of the market upon project completion is the key timing issue.

${ }^{12}$ The mean lag for this regression is estimated by $(1-\delta) / \delta$ where $\beta_{3}=(1-\delta)$ or $\beta_{3} /(1-$ $\beta_{3}$ ), where $\beta_{3}$ is the value of the lagged space coefficient (Pindyck and Rubinfeld, 1981, p. $233)$. In this case the mean lag is about 8.1 years $(0.890 / 1-0.890)$, meaning half the impact of a change in retail space takes place in approximately 8.1 years. This estimate is somewhat larger than studies estimates of 4.2 years by Benjamin, Jud and Okoruwa (1993) and 5.3 years by Benjamin, Jud and Winkler (1995). However, these studies were limited to time periods of 1988 and 1989-91, respectively. 
13By contrast, Wheaton (1987) estimates that the average construction time for office space is approximately two years while Wheaton and Torto (1990) report that the construction time for industrial space is less than one year.

14Retail space investment decisions unlike financial asset investment decisions also involve substantial transaction costs such as zoning, architectural and financing fees that add to land cost. According to Kling and McCue (1987), these transactions costs are irreversible and vary based upon locale.

15Once undertaken, few developers would stop a retail development because of the costs incurred associated with their default on lease contracts and the irreversible transaction costs associated with their re-zoning, construction and financing efforts.

\section{References}

Barth, J. R, M. D. Bradley, J. A. McKenzie and G. S. Sirmans, Stylized Facts about Housing and Construction Activity during the Post-World War II Period, Real Estate Market Analysis, Edited by J. Clapp and S. Messner, New York, NY: Praeger, 1988.

Benjamin, J. D., G. D. Jud and A. A. Okoruwa, Forecasting the Stock of Retail Space Using the Koyck Distributed Lag Model, Journal of Property Research, 1993, 10, 185-92.

Benjamin, J. D., G. D. Jud and D. T. Winkler, An Analysis of Shopping Center Investment, Journal of Real Estate Finance and Economics, 1995, 10, 161-68.

Eppli, M. J. and J. D. Shilling, Speed of Adjustment in Commercial Real Estate Markets, Southern Economic Journal, 1995, 61, 1127-45.

Greene, W. H., Econometric Analysis, second edition, New York: Macmillan Publishing Co., 1993.

Grenadier, S. R., Local and National Determinants of Office Vacancies, Journal of Urban Economics, 1995a, 37, 57-71.

, The Persistence of Real Estate Cycles, Journal of Real Estate Finance and Economics, 1995b, 10, 95-19.

Kling, J. L. and T. E. McCue, Office Building Investment and the Macroeconomy: Empirical Evidence, 1973-1985, Journal of the American Real Estate and Urban Economics Association, 1987, 15, 234-55.

Pindyck, R. S. and D. L. Rubinfeld, Econometric Models and Economic Forecasts, second edition, New York: McGraw-Hill, 1981.

Rose, L. A., Urban Land Supply: Natural and Contrived Restrictions, Journal of Urban Economics, 1989a, 25, 325-45.

, Topographical Constraints and Urban Land Supply Indexes, Journal of Urban Economics, $1989 \mathrm{~b}, 26,335-47$.

Wheaton, W. C., The Cyclic Behavior of the National Office Market, Journal of the American Real Estate and Urban Economics Association, 1987, 15, 281-99.

Wheaton, W. C. and R. G. Torto, An Investment Model of the Demand and Supply for Industrial Real Estate, Journal of the American Real Estate and Urban Economics Association, 1990, $18,530-47$.

The authors gratefully acknowledge the Real Estate Research Institute for their financial support. The authors also appreciate the comments and suggestions from two anonymous

reviewers, David Geltner, William McCollum of the O'Connor Group, Jianping Mei and participants of a session on retail real estate at the 1996 American Real Estate Society Meetings as well as participants of the 1996 Real Estate Research Institute Seminar 